Prepared in cooperation with the Indiana Department of Transportation

\title{
Flood-Inundation Maps for the Salamonie River at Portland, Indiana
}

Scientific Investigations Report 2018-5132 
Cover. Example of a flood-inundation map for the Salamonie River at Portland, Indiana. 


\section{Flood-Inundation Maps for the Salamonie River at Portland, Indiana}

By Kellan R. Strauch

Prepared in cooperation with the Indiana Department of Transportation

Scientific Investigations Report 2018-5132 


\section{U.S. Department of the Interior \\ RYAN K. ZINKE, Secretary}

\section{U.S. Geological Survey James F. Reilly II, Director}

\section{U.S. Geological Survey, Reston, Virginia: 2018}

For more information on the USGS - the Federal source for science about the Earth, its natural and living resources, natural hazards, and the environment-visit https://www.usgs.gov or call 1-888-ASK-USGS.

For an overview of USGS information products, including maps, imagery, and publications, visit https://store.usgs.gov.

Any use of trade, firm, or product names is for descriptive purposes only and does not imply endorsement by the U.S. Government.

Although this information product, for the most part, is in the public domain, it also may contain copyrighted materials as noted in the text. Permission to reproduce copyrighted items must be secured from the copyright owner.

Suggested citation:

Strauch, K.R., 2018, Flood-inundation maps for the Salamonie River at Portland, Indiana: U.S. Geological Survey Scientific Investigations Report 2018-5132, 9 p., https://doi.org/10.3133/sir20185132.

ISSN 2328-0328 (online) 


\section{Acknowledgments}

The author wishes to thank the Indiana Department of Transportation for funding the operation and maintenance of the streamgage used for this study. Special thanks are given to the National Weather Service for their continued support of the U.S. Geological Survey Flood-Inundation Mapping Program. 



\section{Contents}

Acknowledgments ……...................................................................................................................

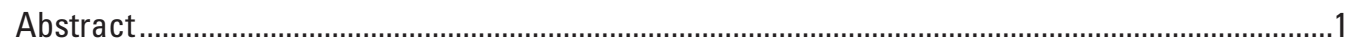

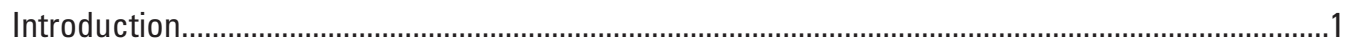

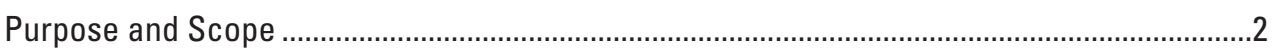

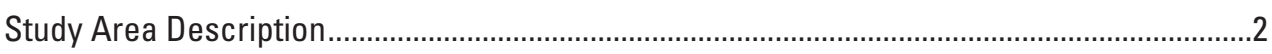

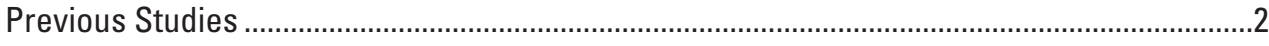

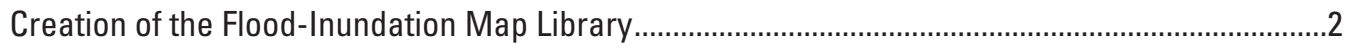

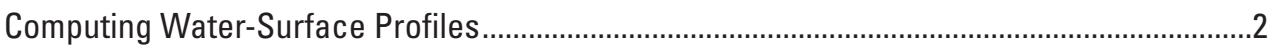

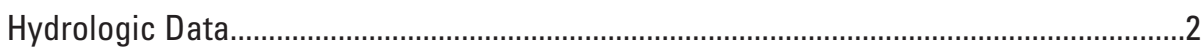

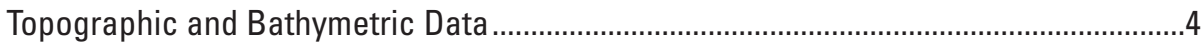

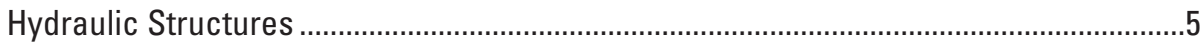

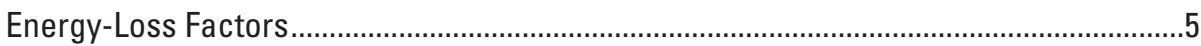

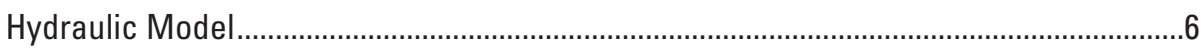

Development of Water-Surface Profiles .......................................................................

Developing Flood-Inundation Maps ………….................................................................6

Flood-Inundation Map Delivery ...................................................................................

Disclaimer for Flood-Inundation Maps ............................................................................

Uncertainties and Limitations Regarding Use of Flood-Inundation Maps .......................7

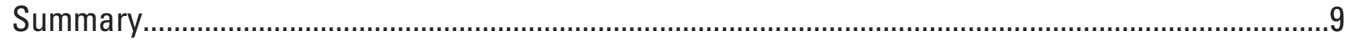

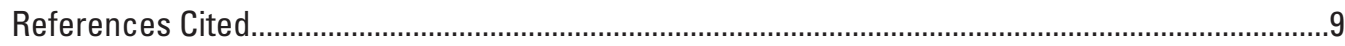

\section{Figures}

1. Map showing the location of study reach for the Salamonie River at Portland, Indiana, and location of U.S. Geological Survey streamgage

2. Map showing a flood-inundation map corresponding to a stage of 18.7 feet at the U.S. Geological Survey Salamonie River at Portland, Indiana, streamgage (station 03324200).

\section{Tables}

1. U.S. Geological Survey streamgage information for Salamonie River at Portland, Indiana.

2. The 1-percent annual exceedance probability discharges for selected sites on the Salamonie River at Portland, Indiana.

3. Estimated discharges for corresponding stages and water-surface elevations at selected locations used in the hydraulic model of the Salamonie River at Portland, Indiana.

4. Calibration of model to target water-surface elevations at the U.S. Geological Survey streamgage on Salamonie River at Portland, Indiana (station 03324200). 


\section{Conversion Factors}

U.S. customary units to International System of Units

\begin{tabular}{lcl}
\hline \multicolumn{1}{c}{ Multiply } & By & \multicolumn{1}{c}{ To obtain } \\
\hline foot $(\mathrm{ft})$ & Length & meter $(\mathrm{m})$ \\
mile $(\mathrm{mi})$ & 0.3048 & kilometer $(\mathrm{km})$ \\
\hline & 1.609 & \\
\hline square mile $\left(\mathrm{mi}^{2}\right)$ & Area & square kilometer $\left(\mathrm{km}^{2}\right)$ \\
\hline & 2.590 & \\
\hline cubic foot per second $\left(\mathrm{ft}^{3} / \mathrm{s}\right)$ & Flow rate & cubic meter per second $\left(\mathrm{m}^{3} / \mathrm{s}\right)$ \\
\hline
\end{tabular}

\section{Datum}

Vertical coordinate information is referenced to (1) stage, the height above an arbitrary datum established at a streamgage, and (2) elevation, the height above the North American Vertical Datum of 1988 (NAVD 88).

Horizontal coordinate information is referenced to the North American Datum of 1983 (NAD 83). 


\title{
Flood-Inundation Maps for the Salamonie River at Portland, Indiana
}

\author{
By Kellan R. Strauch
}

\section{Abstract}

Digital flood-inundation maps for a 6.5-mile reach of the Salamonie River at Portland, Indiana, were created by the U.S. Geological Survey (USGS) in cooperation with the Indiana Department of Transportation. The flood-inundation maps, which can be accessed through the USGS Flood Inundation Mapping Science website at https://water.usgs.gov/osw/flood inundation/, depict estimates of the areal extent and depth of flooding corresponding to selected water levels (stages) at the USGS streamgage on the Salamonie River at Portland, Ind. (station 03324200). Near-real-time stages at this streamgage may be obtained from the USGS National Water Information System web interface at https://doi.org/10.5066/F7P55KJN or from the National Weather Service Advanced Hydrologic Prediction Service (site PORI3) at https:/water.weather.gov/ahps/.

Flood profiles were computed for the stream reach by means of a one-dimensional step-backwater model. The model was calibrated using the current (2018) stage-discharge relation at the Salamonie River at Portland, Ind., streamgage.

The hydraulic model then was used to compute nine water-surface profiles for flood stages at 1-foot (ft) intervals referenced to the streamgage datum and ranging from $10.7 \mathrm{ft}$ or near bankfull to $18.7 \mathrm{ft}$, which equals the highest point on the streamgage rating curve. The simulated water-surface profiles then were combined with a geographic information system digital elevation model derived from light detection and ranging data having a 0.49 -ft root mean square error and 4.9-ft horizontal resolution resampled to a 10-ft grid to delineate the area flooded at each stage. The availability of these maps, along with information regarding current stage from the USGS streamgage, will provide emergency management personnel and residents with information that is critical for flood response activities such as evacuations and road closures, as well as for postflood recovery efforts.

\section{Introduction}

The city of Portland, Indiana, in central Jay County, has a population of 6,223 (U.S. Census Bureau, 2010). Peak streamflows (since 1960) and continuous stage measurements (since 1984) have been recorded at a U.S. Geological Survey (USGS) streamgage on the Salamonie River at Portland, Ind. (station 03324200). The peak discharge of record, 5,310 cubic feet per second $\left(\mathrm{ft}^{3} / \mathrm{s}\right)$ at a stage of $16.76 \mathrm{feet}(\mathrm{ft}$; streamgage datum), was on July 14, 2015.

Before this study, emergency responders in Portland relied on several information sources to make decisions on how to best alert the public and mitigate flood damages. One source is the Federal Emergency Management Agency flood insurance study for Jay County, dated March 17, 2014 (Federal Emergency Management Agency, 2014). A second source of information is the USGS streamgage, Salamonie River at Portland, Ind., from which current (U.S. Geological Survey, 2017a) and historical (since 1960, U.S. Geological Survey, 2017a) water levels and discharges, including annual peak flows, can be obtained. A third source of flood-related information is the National Weather Service (NWS) Advanced Hydrologic Prediction Service (AHPS), which contains the USGS stage data from the Portland streamgage (National Weather Service, 2017).

Although the current stage at a USGS streamgage is particularly useful for residents near a streamgage, it is of limited use to residents farther upstream or downstream because the water-surface elevation is not constant along the stream reach. Knowledge of a water level at a streamgage is difficult to translate into depth and areal extent of flooding at points distant from the streamgage. One way to address these informational gaps is to produce a library of flood-inundation maps that are referenced to the stages recorded at the USGS streamgage. By referring to the appropriate map, emergency responders can discern the severity of flooding (depth of water and areal extent), identify roads that are or will soon be flooded, and make plans for notifying or evacuating residents at risk of flooding for some distance upstream and downstream from the streamgage. In addition, the capability to visualize the potential extent of flooding has motivated residents to take precautions and heed warnings that they previously might have disregarded. In 2017, the USGS, in cooperation with the 
Indiana Department of Transportation, completed a project to produce a library of flood-inundation maps for the Salamonie River at Portland, Ind.

\section{Purpose and Scope}

This report describes the development of a series of estimated flood-inundation maps for the Salamonie River at Portland, Ind., and identifies where the maps can be viewed electronically and where ancillary data (geographic information system [GIS] flood polygons and depth grids) can be downloaded. The study covers a 6.5 -mile (mi) reach along the Salamonie River, $0.5 \mathrm{mi}$ upstream from the State Route 26 Bridge to 0.25 mi downstream from the County Road 75 Bridge (fig. 1).

The maps were produced for flood levels referenced to the stage recorded at the USGS streamgage on the Salamonie River at Portland, Ind. (fig. 1; table 1); the streamgage is on the downstream side of the County Road 75 Bridge. The maps cover a range in stage from 10.7 to $18.7 \mathrm{ft}$, streamgage datum. The $10.7-\mathrm{ft}$ stage is about bankfull, and the $18.7-\mathrm{ft}$ stage is the highest point on the streamgage rating curve. The datasets (depth grids and shapefiles) used in this study are available through a USGS data release at https://doi.org/10.5066/ F7VM4BJD (Strauch, 2018).

\section{Study Area Description}

The study reach of the Salamonie River is in Jay County (not shown) in the eastern part of Indiana. The drainage area of the reach ranges from 45.4 square miles $\left(\mathrm{mi}^{2}\right)$ at the upstream extent of the study area to $85.8 \mathrm{mi}^{2}$ at the downstream extent of the study reach (U.S. Geological Survey, 2017b). The drainage area of the streamgage at Salamonie River at Portland is $85.6 \mathrm{mi}^{2}$. The headwaters originate in eastern Jay County, and the stream generally flows to the west. The study reach is $6.5 \mathrm{mi}$ long and has an approximate channel slope of 0.00051 (2.7 feet per mile). Land use along the study reach varies among residential, commercial, recreational, and agricultural development. The main channel within the study reach has 10 road crossings and 2 railroad bridges that can affect the water-surface profiles.

\section{Previous Studies}

The current flood insurance study for Jay County (Federal Emergency Management Agency, 2014), which includes Portland, Ind., was completed in 2014 by Christopher B. Burke, Ltd. That study provided information on the 1-percent annual exceedance probability peak discharges, water-surface profiles, and associated flood-plain maps for the Salamonie River (table 2).

\section{Creation of the Flood-Inundation Map Library}

The USGS has standardized the procedures for creating flood-inundation maps for flood-prone communities (U.S. Geological Survey, 2017c) so that the process followed and products produced are similar regardless of which USGS office is responsible for the work. Tasks specific to developing the flood maps for Portland, Ind., include (1) collecting topographic and bathymetric data for selected cross sections and geometric data for structures and bridges along the study reach, (2) estimating energy-loss factors (Manning's roughness coefficients) in the stream channel and flood plain and determining steady-flow data, (3) computing water-surface profiles using the U.S. Army Corps of Engineers Hydrologic Engineering Centers River Analysis System (HEC-RAS) computer program (Brunner, 2016a, b, c), (4) producing estimated flood-inundation maps at various stream stages using the U.S. Army Corps of Engineers Hydrologic Engineering Centers Geospatial River Analysis System (HEC-GeoRAS) computer program (Ackerman, 2012) and GIS, and (5) preparing the maps, as shapefile polygons that depict the areal extent of flood inundation and as depth grids that provide the depth of floodwaters, for display on a USGS flood-inundation mapping application.

\section{Computing Water-Surface Profiles}

The water-surface profiles used to produce the nine flood-inundation maps in this study were computed using HEC-RAS, version 5.0.3 (Brunner, 2016a, c). HEC-RAS is a one-dimensional step-backwater model for simulation of water-surface profiles with steady-state (gradually varied) or unsteady-state flow computation options.

\section{Hydrologic Data}

The study reach includes one streamgage (station 03324200 , fig. 1 ; table 1). Stage is measured every 15 minutes, transmitted hourly by a satellite radio, and made available through the USGS National Water Information System web interface (NWISWeb) (U.S. Geological Survey, 2017a). Stage data from this streamgage are referenced to a local datum but can be converted to water-surface elevations referenced to the North American Vertical Datum of 1988 (NAVD 88) by adding $877.03 \mathrm{ft}$. Continuous records of streamflow are computed from a stage-discharge relation, which has been developed for the streamgage, and are available through the USGS NWISWeb (U.S. Geological Survey, 2017a). 


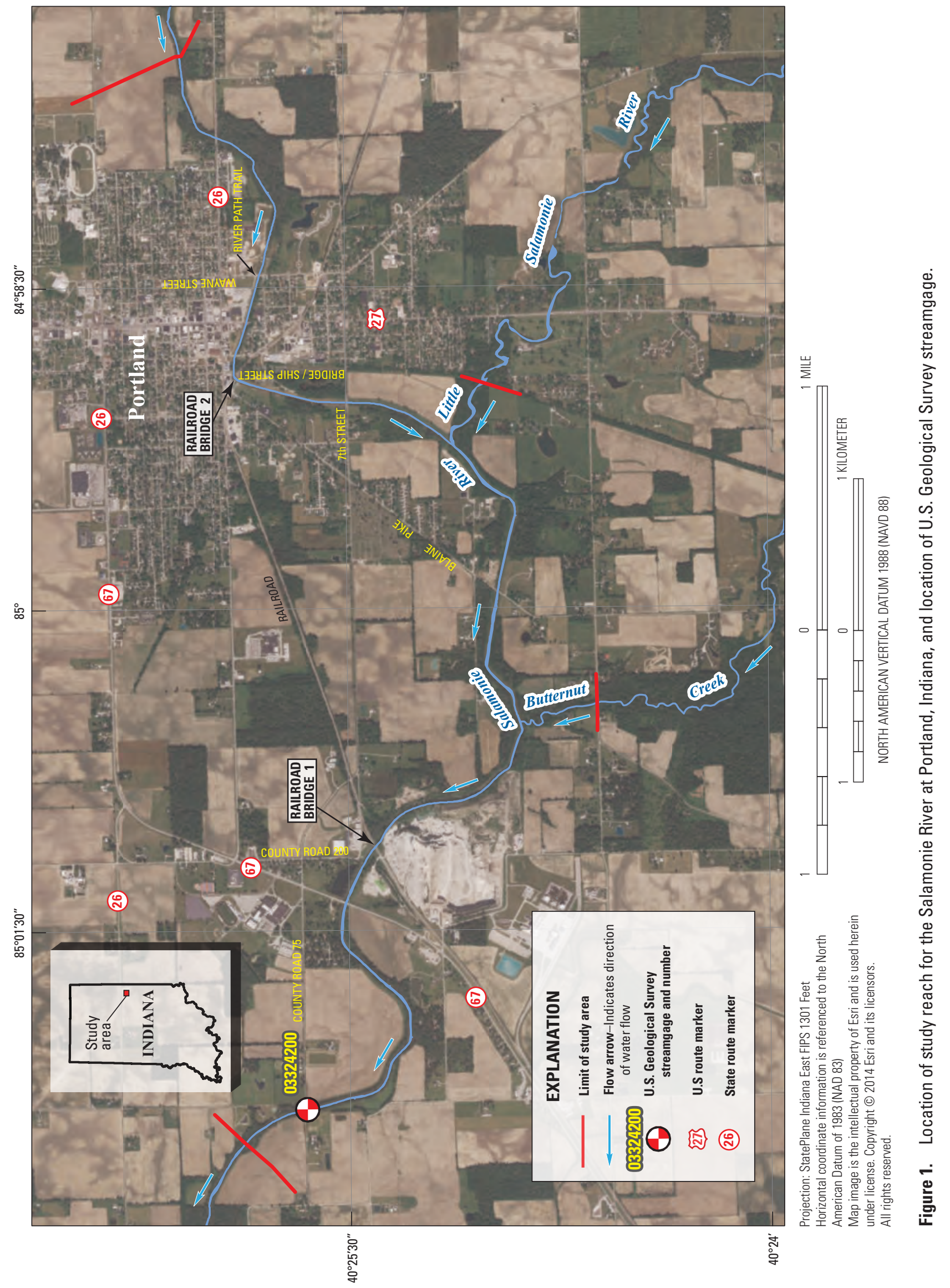


Table 1. U.S. Geological Survey streamgage information for Salamonie River at Portland, Indiana.

[Station location is shown in figure 1. ${ }^{\circ}$, degree; ', minute; ", second; NAVD 88, North American Vertical Datum of 1988]

\begin{tabular}{ll}
\hline Station name & Salamonie River at Portland, Indiana \\
Station number & 03324200 \\
Drainage area, in square miles & 85.6 \\
Latitude & $40^{\circ} 25^{\prime} 39.8^{\prime \prime}$ \\
Longitude & $85^{\circ} 02^{\prime} 20.4^{\prime \prime}$ \\
Period of peak-flow record (water years $\left.{ }^{1}\right)$ & $1959-93,2015-$ current $(2018)$ \\
Maximum recorded stage, in feet above gage datum & 16.96 \\
$\quad$ Elevation, in feet above NAVD 88 & $(893.99)$ \\
Date & March 5, 1963 \\
Maximum discharge, in cubic feet per second & 5,310 \\
Date & July 14, 2015 \\
\hline
\end{tabular}

${ }^{1}$ Water year is the 12-month period from October 1 of one year through September 30 of the following year and is designated by the calendar year in which it ends.

Table 2. The 1-percent annual exceedance probability discharges for selected sites on the Salamonie River at Portland, Indiana.

[Data from Federal Emergency Management Agency, 2014]

\begin{tabular}{lcc}
\hline \multicolumn{1}{c}{ Location on the Salamonie River } & $\begin{array}{c}\text { Drainage area, } \\
\text { in square miles }\end{array}$ & $\begin{array}{c}\text { Estimated discharge for the } \\
\text { 1-percent annual exceedance probability, } \\
\text { in cubic feet per second }\end{array}$ \\
\hline Upstream from Little Salamonie River & 48 & 4,300 \\
Upstream from Butternut Creek & 71.7 & 5,500 \\
At U.S. Geological Survey streamgage & 85.6 & 6,100 \\
03324200 & & \\
\hline
\end{tabular}

The discharges used in the model simulations (table 3) were from the current (2018) stage-discharge relation (rating number 18, effective January 11, 2017) and corresponded to the target stages (U.S. Geological Survey, 2017a). Two minor tributaries - Little Salamonie River (drainage area of $22.5 \mathrm{mi}^{2}$ ) and Butternut Creek (drainage area of $11.8 \mathrm{mi}^{2}$ ) join the Salamonie River within the 6.5-mi study reach. The streamgage-derived discharges were adjusted, as necessary, to account for tributary inflows (table 3 ). These adjustments were estimated by applying a drainage-area ratio between the tributary drainage area and the drainage area at the streamgage to the main-channel flows and computing an estimated flow contribution for each tributary (Reis, 2007).

\section{Topographic and Bathymetric Data}

All topographic data used in this study are referenced vertically to NAVD 88 and horizontally to the North American Datum of 1983. Cross-section elevation data were obtained from a digital elevation model (DEM) that was derived from light detection and ranging (lidar) data that were collected as part of a statewide project during 2011-13 by Woolpert, Inc., Geospatial Services, Dayton, Ohio (Woolpert, Inc., 2011). The lidar data for Jay County were collected in 2012. The DEM was obtained from the Indiana Spatial Data Portal (Indiana University, 2013). The original lidar data have a horizontal resolution of $4.9 \mathrm{ft}$ and vertical accuracy of $0.98 \mathrm{ft}$ 
Table 3. Estimated discharges for corresponding stages and water-surface elevations at selected locations used in the hydraulic model of the Salamonie River at Portland, Indiana.

[NAVD 88, North American Vertical Datum of 1988]

\begin{tabular}{|c|c|c|c|c|}
\hline \multirow{2}{*}{$\begin{array}{l}\text { Stage of water- } \\
\text { surface profile, } \\
\quad \text { in feet }{ }^{1}\end{array}$} & \multirow{2}{*}{$\begin{array}{c}\text { Water-surface } \\
\text { elevation, } \\
\text { in feet above NAVD } 88\end{array}$} & \multicolumn{3}{|c|}{ Estimated discharge at indicated location, in cubic feet per second } \\
\hline & & $\begin{array}{l}\text { At upstream extent } \\
\text { of study reach }\end{array}$ & $\begin{array}{l}\text { Downstream from confluence } \\
\text { with Little Salamonie River }\end{array}$ & $\begin{array}{l}\text { Downstream from confluence } \\
\text { with Butternut Creek }\end{array}$ \\
\hline 10.7 & 887.73 & 1,090 & 1,560 & 1,810 \\
\hline 11.7 & 888.73 & 1,300 & 1,870 & 2,170 \\
\hline 12.7 & 889.73 & 1,560 & 2,250 & 2,610 \\
\hline 13.7 & 890.73 & 1,910 & 2,740 & 3,180 \\
\hline 14.7 & 891.73 & 2,280 & 3,280 & 3,810 \\
\hline 15.7 & 892.73 & 2,700 & 3,880 & 4,500 \\
\hline 16.7 & 893.73 & 3,160 & 4,540 & 5,260 \\
\hline 17.7 & 894.73 & 3,660 & 5,260 & 6,100 \\
\hline 18.7 & 895.73 & 4,200 & 6,040 & 7,000 \\
\hline
\end{tabular}

${ }^{1}$ Stage is referenced to the gage datum of the U.S. Geological Survey streamgage, Salamonie River at Portland, Indiana (station 03324200).

at a 95-percent confidence level based on a root mean square error of $0.49 \mathrm{ft}$ for the "open terrain" land-cover category. By these criteria, the lidar data support production of 2 -ft contours (Dewberry, 2012). The final DEM, which was resampled to a 10 -ft by 10 -ft grid-cell size to decrease the GIS processing time, has a vertical accuracy of plus or minus $1 \mathrm{ft}$. Using HEC-GeoRAS, a set of procedures, tools, and utilities for processing geospatial data in $\operatorname{ArcGIS}^{\circledR}$ (Esri, 2017), elevation data were extracted from the DEM for 98 cross sections and subsequently were input to the HEC-RAS model. Because lidar data cannot provide ground elevations below the water surface of a stream, channel cross sections were surveyed by USGS field crews during November 2016. Cross-sectional depths were measured using hydroacoustic instrumentation at 46 locations. A differential global positioning system with real-time kinematic technology was used to derive horizontal locations and the elevation of the water-surface at each surveyed cross section.

At a $10-\mathrm{ft}$ by $10-\mathrm{ft}$ grid cell resolution, the DEM does not adequately represent the within-channel geometry. Where possible, DEM-generated cross sections were made to coincide with the locations of the within-channel field-surveyed cross sections. Where the cross sections were able to coincide, within-channel data were merged directly with the DEM data. For all other cross sections, the within-channel data were estimated by interpolation from the closest field-surveyed cross section.

The DEM-generated cross section data were used in conjunction with the RAS Mapper tool in HEC-RAS 5.0.3 to interpolate below-water ground elevations through the study reach (Brunner, 2016b). The RAS Mapper tool interpolates the ground surface between each cross section. The interpolated surface then is used with the DEM-generated cross section data to create a grid of elevation data between two cross sections. In this study, a grid of $10-\mathrm{ft}$ by $10-\mathrm{ft}$ cells was created for the in-channel DEM. The merged DEM, consisting of the lidar and in-channel data, was used to create the remaining 98 DEM-generated cross sections in HEC-GeoRAS for input to the HEC-RAS model. Instructions for creating a terrain model of the channel data are in chapter 2 of the U.S. Army Corps of Engineers "2D Modeling User's Manual," version 5.0 (Brunner, 2016b).

\section{Hydraulic Structures}

A total of 12 structures, consisting of 10 road crossings (State Route 26, River Path Trail, Wayne Street, U.S. Route 27, Bridge/Ship Street, 7th Street, Blaine Pike, Country Road 200, State Route 67, and County Road 75) and 2 railroad bridges, have the potential to affect water-surface elevations during floods along the stream. Bridge-geometry data were obtained from field surveys completed by the USGS and input into the model to simulate the effects of the structures on water-surface elevations. Levees were not in this reach of the Salamonie River.

\section{Energy-Loss Factors}

Hydraulic analyses estimate energy losses that result from frictional resistance exerted by a channel on flow. These energy losses are quantified by the Manning's roughness coefficient ( $n$ value) (Barnes, 1967). Initial (precalibration) $n$ values were selected on the basis of field observations and 
high-resolution aerial photographs. An $n$ value of 0.035 was selected for the main channel with sandy bed and tree-lined banks. The flood plains have mixed land uses but are dominated by agriculture. Forested areas cover wide swaths of land on both banks and flood plains adjacent to the river. Densely populated residential areas are north of the Salamonie River, but these areas are mostly on elevated ground above the flood plain. In these areas, an $n$-value range from 0.022 to 0.088 was presumed to represent the diverse energy-loss factors of these land types, and values within that range were deemed appropriate to use for the initial estimate of the flood plain $n$ value.

As part of the calibration process, the initial $n$ values were adjusted until the differences between simulated and observed water-surface elevations at the streamgage were minimized. The final $n$ values were 0.043 for the main channel and ranged from 0.032 to 0.128 for the overbank areas modeled in this analysis.

\section{Hydraulic Model}

The HEC-RAS analysis for this study was done using the steady-state flow computation option. Steady-state flow data consisted of flow regime, boundary conditions, and flows that produced water-surface elevations at the streamgage cross section that matched target water-surface elevations. These target elevations coincided with even 1-ft increments of stage, referenced to the local streamgage datum. Subcritical (tranquil) flow regime was assumed for the simulations. Normal depth, based on a water-surface slope of 0.00137 , was used as the downstream boundary condition. The calculation of normal depth was estimated from the slope of the channel bottom of the three downstream cross sections in the model. The flows that were used in the model were discussed in the "Hydrologic Data" section.
The HEC-RAS model was calibrated to the current (2018) stage-discharge relation at the Salamonie River streamgage. Model calibration was completed by adjusting Manning's $n$ values until the results of the hydraulic computations closely agreed with the observed water-surface elevations for given flows. Differences between observed and simulated water-surface elevations for the nine simulated flows at the USGS streamgage were equal to or less than $0.25 \mathrm{ft}$ (table 4).

\section{Development of Water-Surface Profiles}

The calibrated hydraulic model was used to generate water-surface profiles for a total of nine stages at 1 - $\mathrm{ft}$ intervals between $10.7 \mathrm{ft}$ and $18.7 \mathrm{ft}$ as referenced to the local datum of the Salamonie River at Portland, Ind., streamgage. These stages correspond to elevations of $887.73 \mathrm{ft}$ and $895.73 \mathrm{ft}$ above NAVD 88, respectively, at the streamgage. Discharges corresponding to the various stages were obtained from the current (2018) stage-discharge relation for the Salamonie River at Portland, Ind., streamgage. Discharges through the study reach were adjusted, as necessary, for tributary inflow(s) as shown in table 3.

\section{Developing Flood-Inundation Maps}

Flood-inundation maps for the 6.5-mi reach of the Salamonie River at Portland, Ind., were created in a GIS by combining the water-surface profiles and DEM data. The DEM data were derived from the same lidar data described previously in the "Topographic and Bathymetric Data" section and, therefore, have an estimated vertical accuracy of $2 \mathrm{ft}$ (that is, plus or minus $1 \mathrm{ft}$ ). Estimated flood-inundation boundaries

Table 4. Calibration of model to target water-surface elevations at the U.S. Geological Survey streamgage on Salamonie River at Portland, Indiana (station 03324200).

[NAVD 88, North American Vertical Datum of 1988]

\begin{tabular}{cccc}
\hline $\begin{array}{c}\text { Stage of water-surface } \\
\text { profile, } \\
\text { in feet }\end{array}$ & $\begin{array}{c}\text { Observed water-surface } \\
\text { elevation, } \\
\text { in feet above NAVD 88 }\end{array}$ & $\begin{array}{c}\text { Simulated } \\
\text { water-surface elevation, } \\
\text { in feet above NAVD 88 }\end{array}$ & $\begin{array}{c}\text { Difference in } \\
\text { elevation, } \\
\text { in feet }\end{array}$ \\
\hline 10.7 & 887.73 & 887.66 & -0.07 \\
11.7 & 888.73 & 888.56 & -0.17 \\
12.7 & 889.73 & 889.48 & -0.25 \\
13.7 & 890.73 & 890.52 & -0.21 \\
14.7 & 891.73 & 891.58 & -0.15 \\
15.7 & 892.73 & 892.65 & -0.08 \\
16.7 & 893.73 & 893.71 & -0.02 \\
17.7 & 894.73 & 894.71 & -0.02 \\
18.7 & 895.73 & 895.70 & -0.03 \\
\hline
\end{tabular}


for each simulated water-surface profile were developed with HEC-GeoRAS software (Ackerman, 2012), which prepares geometric data for import into HEC-RAS and processes simulation results exported from HEC-RAS (Brunner, 2016a c). Shapefile polygons and depth grids of the inundated areas for each profile were modified, as required, in the ArcMap ${ }^{\circledR}$ application of ArcGIS (Esri, 2017) to ensure a hydraulically reasonable transition of the flood boundaries between modeled cross sections.

Any inundated areas that were detached from the main channel were examined to identify subsurface connections with the main river, such as through culverts under roadways. Where such connections existed, the mapped inundated areas were retained in their respective flood maps; otherwise, the erroneously delineated parts of the flood extent were deleted. The flood-inundation areas were overlaid on high-resolution, georeferenced, aerial photographs of the study area. Bridge surfaces are displayed as inundated regardless of the actual water-surface elevation related to the lowest structural chord of the bridge or the bridge deck. Estimates of water depth can be obtained from the depth-grid data that are included with the presentation of the flood maps on an interactive USGS mapping application described in the following section, "Flood-Inundation Map Delivery." The datasets (depth grids and shapefiles) used in this study are available through a data release at https://doi.org/10.5066/F7VM4BJD (Strauch, 2018). The flood map corresponding to the highest simulated watersurface profile, a stage of $18.7 \mathrm{ft}$, is presented in figure 2 .

\section{Flood-Inundation Map Delivery}

The current study documentation is available online at the USGS Publications Warehouse (https://doi.org/10.3133/ sir20185132). Also, a Flood Inundation Mapping Science website (U.S. Geological Survey, 2017c) has been established at https://water.usgs.gov/osw/flood_inundation/ to make USGS flood-inundation study information available to the public. That site links to a mapping application that presents map libraries and provides detailed information on flood extents and depths for modeled sites. The mapping application enables the production of customized flood-inundation maps from the map library for Salamonie River at Portland, Ind. A link on this website connects to the USGS NWISWeb (U.S. Geological Survey, 2017a), which presents the current stage and streamflow at the Salamonie River at Portland, Ind., streamgage, to which the inundation maps are referenced. The estimated flood-inundation maps are displayed in sufficient detail so that preparations for flooding and decisions for emergency response can be completed efficiently. Depending on the flood magnitude, roadways are shown as shaded (inundated and likely impassable) or not shaded (dry and passable) to facilitate emergency planning and use. Bridges are shadedthat is, shown as inundated - regardless of the flood magnitude. A shaded building should not be interpreted to mean that the structure is completely submerged; rather, bare earth surfaces near the building are inundated. In these instances, the water depth (as indicated in the mapping application by holding the cursor over an inundated area) near the building would be an estimate of the water level inside the structure, unless flood-proofing measures had been implemented.

\section{Disclaimer for Flood-Inundation Maps}

The flood-inundation maps should not be used for navigation, regulatory, permitting, or other legal purposes. The USGS provides these maps "as-is" for a quick reference, emergency planning tool but assumes no legal liability or responsibility resulting from the use of this information.

\section{Uncertainties and Limitations Regarding Use of Flood-Inundation Maps}

Although the flood-inundation maps represent the boundaries of inundated areas with a distinct line, some uncertainty is associated with these maps. The flood boundaries shown were estimated on the basis of water stages and streamflows at selected USGS streamgages. Water-surface elevations along the stream reaches were estimated by steady-state hydraulic modeling, assuming unobstructed flow, and using streamflows and hydrologic conditions anticipated at the USGS streamgage(s). The hydraulic model reflects the land-cover characteristics and any bridge, dam, levee, or other hydraulic structures existing as of November 2016. Unique meteorological factors (timing and distribution of precipitation) may cause actual streamflows along the modeled reach to vary from those assumed during a flood, which may lead to deviations in the water-surface elevations and inundation boundaries shown. Additional areas may be flooded due to unanticipated conditions such as changes in the streambed elevation or roughness, backwater into major tributaries along a main stem river, or backwater from localized debris or ice jams. The accuracy of the floodwater extent portrayed on these maps will vary with the accuracy of the digital elevation model used to simulate the land surface.

If this series of flood-inundation maps will be used in conjunction with National Weather Service (NWS) river forecasts, the user should be aware of additional uncertainties that may be inherent or factored into NWS forecast procedures. The NWS uses forecast models to estimate the quantity and timing of water flowing through selected stream reaches in the United States. These forecast models (1) estimate the amount of runoff generated by precipitation and snowmelt, (2) simulate the movement of floodwater as it proceeds downstream, and (3) predict the flow and stage (and water-surface elevation) for the stream at a given location (AHPS forecast point) throughout the forecast period (every 6 hours and 3 to 5 days out in many locations). For more information on AHPS forecasts, please see: http://water.weather.gov/ahps/pcpn_and river_forecasting.pdf.

Additional uncertainties and limitations pertinent to this study may be described elsewhere in this report. 


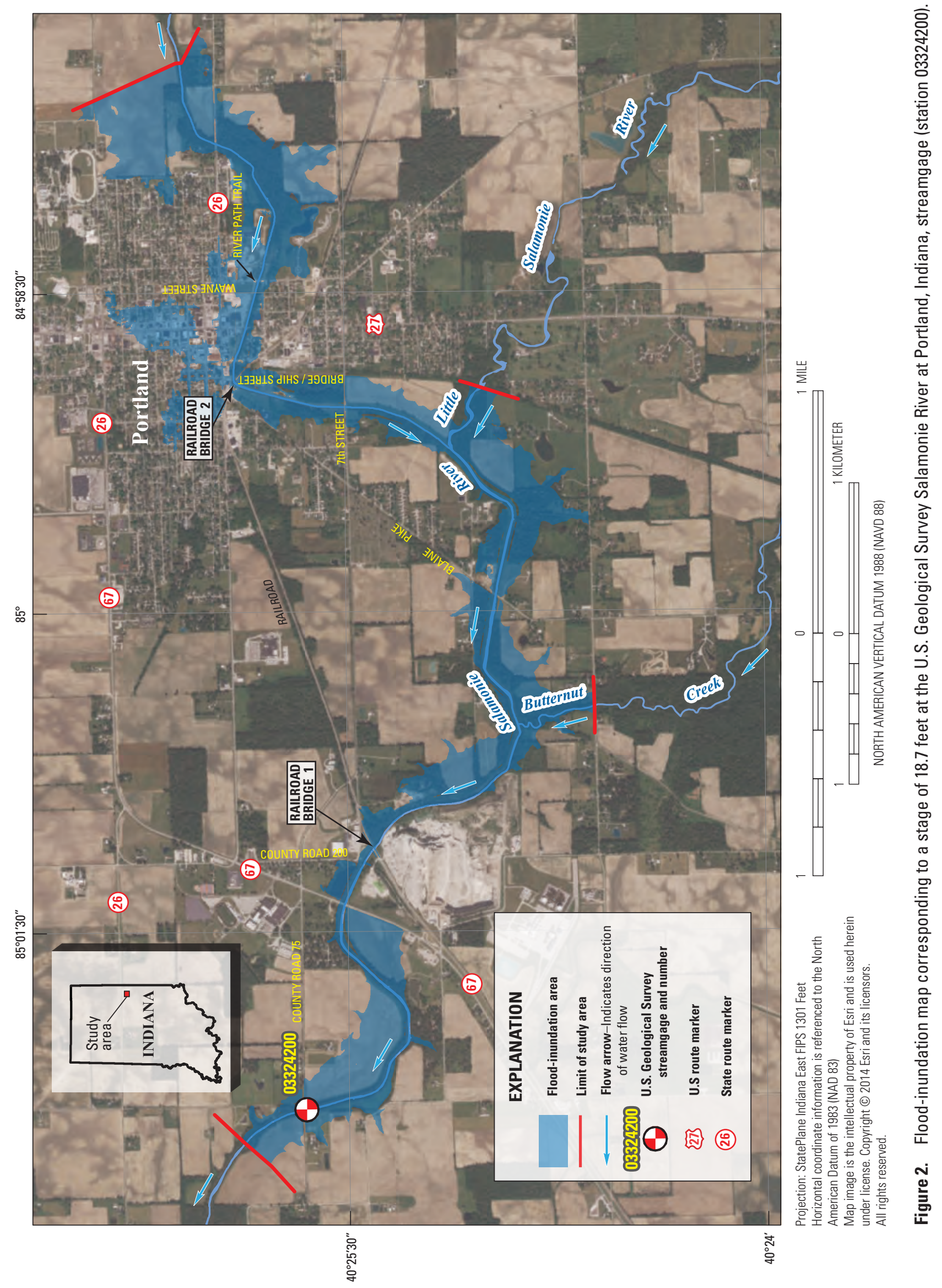




\section{Summary}

A series of nine digital flood-inundation maps were developed by the U.S. Geological Survey (USGS) in cooperation with the Indiana Department of Transportation for the Salamonie River at Portland, Indiana. The maps cover a reach about 6.5 miles long, extending 0.5 miles upstream from the State Route 26 Bridge to 0.25 miles downstream from County Road 75. The maps were developed using the U.S. Army Corps of Engineers Hydrologic Engineering Centers River Analysis System and Hydrologic Engineering Centers Geospatial River Analysis System programs to compute water-surface profiles and to delineate estimated flood-inundation areas and depths of flooding for selected stream stages. The Hydrologic Engineering Centers River Analysis System hydraulic model was calibrated to the current (2018) stage-discharge relation at the USGS streamgage on the Salamonie River at Portland, Ind. (station 03324200). The model was used to compute nine water-surface profiles for flood stages at 1 -foot intervals referenced to the streamgage datum and ranging from 10.7 feet or near bankfull to 18.7 feet, which equals the highest point on the streamgage rating curve. The simulated water-surface profiles then were combined with a Geographic Information System digital elevation model derived from light detection and ranging data to delineate estimated flood-inundation areas as shapefile polygons and depth grids for each profile. These flood-inundation polygons were overlaid on high-resolution, georeferenced aerial photographs of the study area.

Interactive use of the maps on this mapping application can give users a general indication of depth of water at any point by using the mouse cursor to click within the shaded areas. These maps, in conjunction with the real-time stage data from the USGS streamgage, Salamonie River at Portland, Ind., will help to guide users in taking individual safety precautions and will provide emergency management personnel with a tool to manage emergency flood operations and postflood recovery efforts efficiently.

\section{References Cited}

Ackerman, C.T., 2012, HEC-GeoRAS, GIS tools for support of HEC-RAS using ArcGIS 10-User's manual, ver. 10: Davis, Calif., U.S. Army Corps of Engineers, 242 p.

Barnes, H.H., Jr., 1967, Roughness characteristics of natural channels: U.S. Geological Survey Water-Supply Paper $1849,219 \mathrm{p}$.

Brunner, G.W., 2016a, HEC-RAS River Analysis System-Hydraulic reference manual, ver. 5.0: Davis, Calif., U.S. Army Corps of Engineers, 446 p.

Brunner, G.W., 2016b, HEC-RAS River Analysis System2D modeling user's manual, ver. 5.0: Davis, Calif., U.S. Army Corps of Engineers, 171 p.
Brunner, G.W., 2016c, HEC-RAS River Analysis SystemUser's manual, ver. 5.0: Davis, Calif., U.S. Army Corps of Engineers, $960 \mathrm{p}$.

Dewberry, 2012, National Enhanced Elevation Assessment: Fairfax, Va., Dewberry, 84 p., accessed July 9, 2013, at http://www.dewberry.com/docs/default-source/documents/ neea_final-report_revised-3-29-12.pdf? sfvrsn $=0$.

Esri, 2017, ArcGIS: Esri web page, accessed July 1, 2017, at http://www.esri.com/software/arcgis/.

Federal Emergency Management Agency, 2014, Flood Insurance Study, Jay County, Indiana, and incorporated areas: Washington D.C., Federal Emergency Management Agency, 19 p., 4 pl.

Indiana University, 2013, Indiana spatial data portal: Indiana University web page, accessed January 25, 2017, at http://gis.iu.edu/.

National Weather Service, 2017, Advanced Hydrologic Prediction Service, Salamonie River at Portland, Indiana: National Oceanic and Atmospheric Administration web page, accessed June 20, 2017, at http://water.weather.gov/ahps2/ hydrograph.php?wfo=iwx\&gage=PORI3 .

Ries, K.G., III, 2007, The national streamflow statistics program-A computer program for estimating streamflow statistics for ungaged sites: U.S. Geological Survey Techniques and Methods, book 4, chap. A6, 37 p.

Strauch, K.R., 2018, Flood-inundation geospatial datasets for the Salamonie River at Portland, Indiana: U.S. Geological Survey data release, https://doi.org/10.5066/F7VM4BJD.

U.S. Census Bureau, 2010, 2010 Census interactive population search, IN-Indiana: U.S. Census Bureau web page, accessed June 28, 2017, at http://www.census.gov/2010census/ popmap/ipmtext.php?fl=18.

U.S. Geological Survey, 2017a, USGS water data for the Nation: U.S. Geological Survey National Water Information System database, accessed June 25, 2017, at https://doi.org/10.5066/F7P55KJN.

U.S. Geological Survey, 2017b, StreamStats: U.S. Geological Survey web page, accessed June 25, 2017, at https://streamstats.usgs.gov/ss/.

U.S. Geological Survey, 2017c, USGS flood inundation mapping science: U.S. Geological Survey web page, accessed June 19, 2017, at https://water.usgs.gov/osw/ flood_inundation.

Woolpert, Inc., 2011, Indiana statewide digital orthoimagery, 2011 Indiana statewide imagery and LiDAR program: Dayton, Ohio, Woolpert, Inc. [Metadata available at http://gis.iu.edu/files/documents/in2011_ortho.txt.] 
For more information about this publication, contact:

Director, USGS Ohio Kentucky Indiana Water Science Center

5957 Lakeside Blvd.

Indianapolis, IN 46278

317-290-3333

For additional information, visit: https://www.usgs.gov/centers/oki-water

Publishing support provided by the

Rolla Publishing Service Center 



\section{$\frac{\mathbb{2}}{3}$}

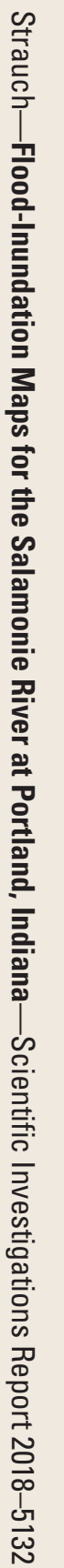

